This article has been accepted for publication in a revised form in Social Policy and Society https://doi.org/10.1017/S1474746419000320. This version is free to view and download for private research and study only. Not for re-distribution, re-sale or use in derivative works. (C) Cambridge University Press 2019.

\title{
The legacy of the Right to Buy and the differentiation of older home owners
}

\section{Dr Vikki McCall (corresponding author)}

Senior Lecturer in Social Policy and Housing

Room 4S5, Colin Bell Building, Faculty of Social Sciences, University of Stirling,

Stirling, Scotland

Vikki.mccall@stir.ac.uk

01786467698

Dr Madhu Satsangi

Lecturer (Urban Studies),

School of Social and Political Sciences, University of Glasgow, Glasgow

Madhu.Satsangi@glasgow.ac.uk

Dr Corinne Greasley- Adams

Research Fellow

Faculty of Social Sciences, University of Stirling, Stirling, Scotland

corinne.greasley-adams@stir.ac.uk

\section{Keywords}

Right to buy; ageing population; housing choice; housing policy; owner occupiers

\section{Acknowledgments}

We appreciate the support of the funders of the research: the Scottish Futures Trust and Stirling Council, for their support and assistance in the conduct of the research. We also 
acknowledge the support of voluntary sector housing and related agencies, and of older home-owners and their families, in participating. All of the views expressed are our own.

\title{
The legacy of the Right to Buy and the differentiation of older home owners
}

\begin{abstract}
This paper explores older owner occupiers in lower value properties who, having acquired their home through the Right to Buy (RTB) in the 1980s, are now experiencing housing-related challenges in older age. This paper outlines the views and perceptions of older owner occupiers, social landlords, voluntary groups and housing organisations to explore the legacy of the RTB. Current and future policy challenges in the area include the differentiation of home owners, difficulties of selling property with low equity in older age and the relationship between health and housing. This paper calls to widen the analysis of the long-term impact of the RTB to owner occupiers in lower value properties and notes that 'ageing in place' goes beyond looking at people's current house to the linked housing choices available to them. We recommend that policy support be extended to older home owners to increase housing choice in older age.
\end{abstract}

\section{Introduction}

Housing and ageing has been an increasing political and policy concern due to the UK's housing sector being 'woefully underprepared for ageing' (Select Committee on Public Service and Demographic Change, 2013). This paper focuses on a generally overlooked group: older home owners ${ }^{1}$ in lower valued properties. We focus on experiences of owner occupiers and the views and perceptions of social landlords, voluntary groups and organisations in central Scotland. This paper explores home ownership in older age and asks the question: What role has the Right to Buy (RTB) policy in the UK had in the differentiation of older home owners? We focus on the role of the Right to Buy (RTB) policy in the UK due to it being a significant piece of legislation that made the privatisation of the UK social housing sector mandatory from

\footnotetext{
${ }^{1}$ Home owners, owner occupiers and home-ownership are used in this paper to describe the tenure of those people and participants who own (whether outright or mortgaged) the house in which he or she lives. In the case of this project it does not include shared equity or shared ownership related properties
} 
1980. This paper shows the repercussions for older people's housing pathways and the UK's ability to prepare for the needs of its ageing population.

Homeownership in the UK is built on a 'cultural norm' and assumption that it guarantees security and independence (McKee, 2011). Due to this, owner occupiers in lower valued properties have often been overlooked as a group due to assumptions of wealth and security. This has been reinforced by policy discourses that have tended to treat older people as a homogenous group, facing common problems, with social policy overlooking inequalities in older age (Walker, 1981, 2018). Yet these inequalities have been shown to be significant in places such as the USA as they result in unmet housing needs for lower income older homeowners (Golant, 2008). This paper challenges the assumptions around home ownership and older age, highlighting an emerging group that are living with the ongoing legacy of the Right to Buy policy in the UK.

The RTB in particular and its consequences for public sector housing supply has played a significant role in promoting low cost homeownership in the UK (Forrest and Murie, 1988, Forrest et al., 1995; Jones and Murie, 1999; Pierson, 1994) with over 2.8 million council and social rented homes being sold under the Right to Buy between 1980 and 2015 (Murie, 2016). However, rather less attention has been paid to the longer-term housing careers of these homeowners. For example, much focus has been on the 'losers' rather than the 'gainers' (Forrest and Murie, 1988: 229). This paper gives new insight into the 'winners' to highlight that not all homeowners have benefited in the longer term as housing choice have become limited in older age. The research presented here suggests that the experiences of 'gainers' are not homogeneous and now pose challenges as these home owners age.

\section{Background}

As the UK's population ages, increasing attention has been placed on how the housing, health and social care needs of that population will be met. Care and Repair England (2014) has claimed that a 'Perfect Storm' is brewing, in which the ageing population contains increasing numbers of low income home owners living in decaying housing they cannot maintain and without the ability to finance their care. The Right to 
Buy (a policy introduced in 1980 that allowed those living in public sector housing to buy their home with a generous discount) has had a significant role in the housing choices for older owner occupiers in lower value properties. This is not only because of the significant numbers of purchasers, but also because those most likely to purchase their properties have lived in their homes for over 20 years and are long established tenants planning to stay in their family home (Murie, 2016).

This has remained simultaneously one of the most controversial and popular mass privatisation policies of all time (Goodlad and Atkinson, 2004; Jones and Murie, 2006). Whilst UK Conservative administrations (1979-1997 and from 2010 onwards) broadly sought to increase the uptake of RTB, Labour sought to contain it from 1997-2010. The mass sale of council housing throughout the UK was not accompanied by significant new building or reinvestment in the sector, although there is a diverging picture across Britain. From 1980 - 2013, 2.6m Right to Buy sales were recorded across Britain, with the public sector and housing associations completing 692,000 houses, a 'replacement rate' ${ }^{2}$ of $27 \%$. In Scotland, the comparable figures are 497,000 sales and 98,000 completions giving a replacement rate of $20 \%{ }^{3}$. The history of the RTB has been covered extensively (Forrest and Murie, 1985, 1988, 1995; Forrest et al., 1995; Jones and Murie, 1999, 2006; Pierson, 1994; Goodlad and Atkinson, 2004; Murie, 2016), with much of the literature reflecting on what are generally seen as damaging consequences for social rented housing supply and the future of public landlords rather than the housing careers of those people who utilised the RTB. In a rare example of the latter, Williams and Twine (1992) recognized the RTB as being likely to widen housing choices for existing owners.

Post-devolution Scotland now demonstrates a clear and sharp divide between different nations within the UK, with McKee et al. (2016) noting that there is an increasingly important spatial nuance underpinned by divergent political narratives in different parts of the UK (see also Gibb, 2014). Most notably, 2016 heralded the end of the RTB in Scotland while it is being extended in England. This policy divergence

\footnotetext{
${ }^{2}$ Housing association completions include shared ownership and other low cost home ownership houses, meaning that not all the 'replacement' is like for like.

${ }^{3}$ Rounded figures, data sourced from tables 19 and 20 of Wilcox, S., Perry, J. and Williams, P. (2015) UK Housing Review 2015, Coventry: ClH accessed online at http://www.york.ac.uk/res/ukhr/ukhr15/compendium.htm on May 18, 2016.
} 
echoes through prevalent rhetoric North and South of the border: the Scottish agenda has been to save current and future social housing stock (Scottish Government, 2014), also acknowledging that "... many of those who exercised their right to buy have struggled to meet the costs of home ownership" (Scottish Government, 2013: 2). Furthermore, McKee (2010) has questioned the long-standing concerns as to whether the responsibilities of home ownership make it the most appropriate tenure 'solution' for lower income households. The next section looks at this in more detail.

\section{The differential experience of home ownership and the Right to Buy}

Writing in 2006, Jones and Murie noted that over two million households had exercised their RTB in the UK and their analysis shows that not all purchasers have had the same experiences. Bringing more households directly into the housing market has extended the reach of its episodes of boom and slump (Forrest et al, 1990: 3). The 2007 global financial crisis has demonstrated how pervasive the impacts of boom and slump might be, particularly for households at the lower end of the income spectrum (Hills et al, 2013). Homeownership has been linked to a stereotypical image of investment, mobility, independence and security when in reality the experience of homeownership varies with time, context and by social group (Forrest et al., 1990). Neither the receipt of general and particular benefits associated with the tenure, nor the impact of costs, is evenly distributed across the spectrum of owners. Summarising evidence from England in the 1980s, Saunders (1990) notes that '(t)he contrasts within this tenure (i.e., home ownership) ....can be every bit as striking as those which separate owners from renters' (Saunders, 1990: 134). Looking further back, Merrett and Gray (1982: 275) refer to the understanding by the UK Government ${ }^{4}$ during the Second World War that home owners did not always enjoy well-constructed houses that financing purchase unduly strained the resources of some owners and that ownership growth might hinder labour mobility.

In the period since home ownership became the majority tenure, that is since 1971 for England and Wales (Wilcox et al, 2015: Table 17) and since 1990 for Scotland (Scottish Government, 2015), analysis of separate national house condition surveys has drawn attention to the higher rates of disrepair and poor housing condition in the

\footnotetext{
${ }^{4}$ Central Housing Advisory Committee (1944) Private Enterprise Housing, London: HMSO
} 
dwellings owned by low income owners, commonly related to the inability to afford to effective repair (Revell and Leather, 2000) and in those owned by elderly owners unwilling to undergo the stress of contracting repair work (Leather and Moseley, 2002). Further, Dorling argues that it was only in the 1980s that '...otherwise apparently 'respectable' home-purchasing residents started to get into arrears on their mortgages' (Dorling, 2015: 163 -164). Drawing on General Household Survey and English House Condition Survey data, Forrest and Leather (1998: 35) anticipated an increase in the number of very old home owners experiencing poor housing conditions and a reduction in the likelihood of older home owners' aspirations being realizable due to limited equity and a lack of moving opportunities.

Arrears problems and the inability to afford repair costs tend to become more likely with earners in a household on lower or more uncertain incomes (as well as with greater macroeconomic volatility). In turn, these correlate with lower socio-economic status and as home ownership has grown, more households of lower socio-economic status have become owners. Thus, across Britain in 1971-72 (according to the General Household Survey), almost a half of all households were home owners, the rate in Scotland was 27.9 per cent. The rate ranged from three households in four with a head classified as an employer or manager to one unskilled manual worker in five (Table 1). By 1981 (i.e., approximately the time the Right to Buy was introduced), Britain's home ownership rate had increased to 53.2 per cent (and Scotland's to 32.9 per cent). As shown in Table 1, that overall increase was associated with some significant increases in the home ownership rate in households of modest socio-economic status (as well as amongst professional households). Nevertheless, in Scotland in 1981 only about one household in four with a skilled manual head of household (or personal service employee) owned its own home. The figure across Britain as a whole was over twice that.

Table 1 Home ownership rate by socio-economic group of head of household (SEG), GB 1972-73 and 1981, Scotland $1981^{i}$

\begin{tabular}{|c|c|c|c|}
\hline \multirow[t]{2}{*}{ SEG (selected) } & \multicolumn{3}{|c|}{$\%$ of households in home-ownership } \\
\hline & GB 1972-73 & GB 1981 & $\begin{array}{l}\text { Scotland, } \\
1981\end{array}$ \\
\hline $\begin{array}{l}\text { Professionals } \\
\text { Employers and managers }\end{array}$ & $\begin{array}{l}73.4 \\
75.5\end{array}$ & $\begin{array}{l}85.9 \\
81.4\end{array}$ & $\begin{array}{l}69.6 \\
79.9\end{array}$ \\
\hline
\end{tabular}


Junior non-manual

Skilled manual workers and own account non-professionals

Semi-skilled manual workers and personal service employees

Unskilled manual workers

Retired*

All households
55.0

44.9

33.0

20.3

45.8

49.2

$(\mathrm{N}=11,398)$
64.1

54.8

44.1

26.3

40.4

17.4

28.6

11.1

45.8

27.7

$53.2 \quad 32.9$

${ }^{1}$ Note: * In 1972-73 proxied by head of household aged 60 and above.

Sources: Office for Population Censuses and Statistics (OPCS, now ONS) (1975) General Household Survey 1972-73, London Tables 2.2 and 2.10: HMSO; Office of Population Censuses and Surveys, 1981 Census: Aggregate data (England and Wales) [computer file]. UK Data Service Census

Support. Downloaded from:http://casweb.mimas.ac.uk. This information is licensed under the terms of the Open Government Licence [http://www.nationalarchives.gov.uk/doc/open-governmentlicence/version/2]; Registrar General for Scotland, 1981 Census: Aggregate data (Scotland) [computer file]. UK Data Service Census Support. Downloaded from: http://casweb.mimas.ac.uk. This information is licensed under the terms of the Open Government Licence

[http://www.nationalarchives.gov.uk/doc/open-government-licence/version/2].

Similarly to the UK as a whole, the RTB in Scotland clearly played a major role in extending the number of home owners. Thus, between 1980 and 2014, there were just over half a million private sector new build completions across Scotland $(554,633$; data sourced from http://www.gov.scot/Resource/0047/00478069.xls on June 4, 2015) and just under half a million local authority right to buy sales $(433,378$; data sourced from http://www.gov.scot/Resource/0047/00478002.xls on June 4, 2015). The number of sales grew from 4,576 in 1980-81 to 33,391 in 1989-90 falling back to 12,972 in 1996-97. Apart from something of a spurt in 2002-03 (17,333 sales), numbers then declined to the order of 1,200 per annum in the current decade (Figure $1)^{5}$.

\footnotetext{
${ }^{5}$ At this point it may be observed that the aspired move to save social housing stocks through ending the RTB is potentially rather less dramatic in scale than it might have been if it had been enacted earlier.
} 
Figure 1 Council house sales $1979-80$ to $2013-14$

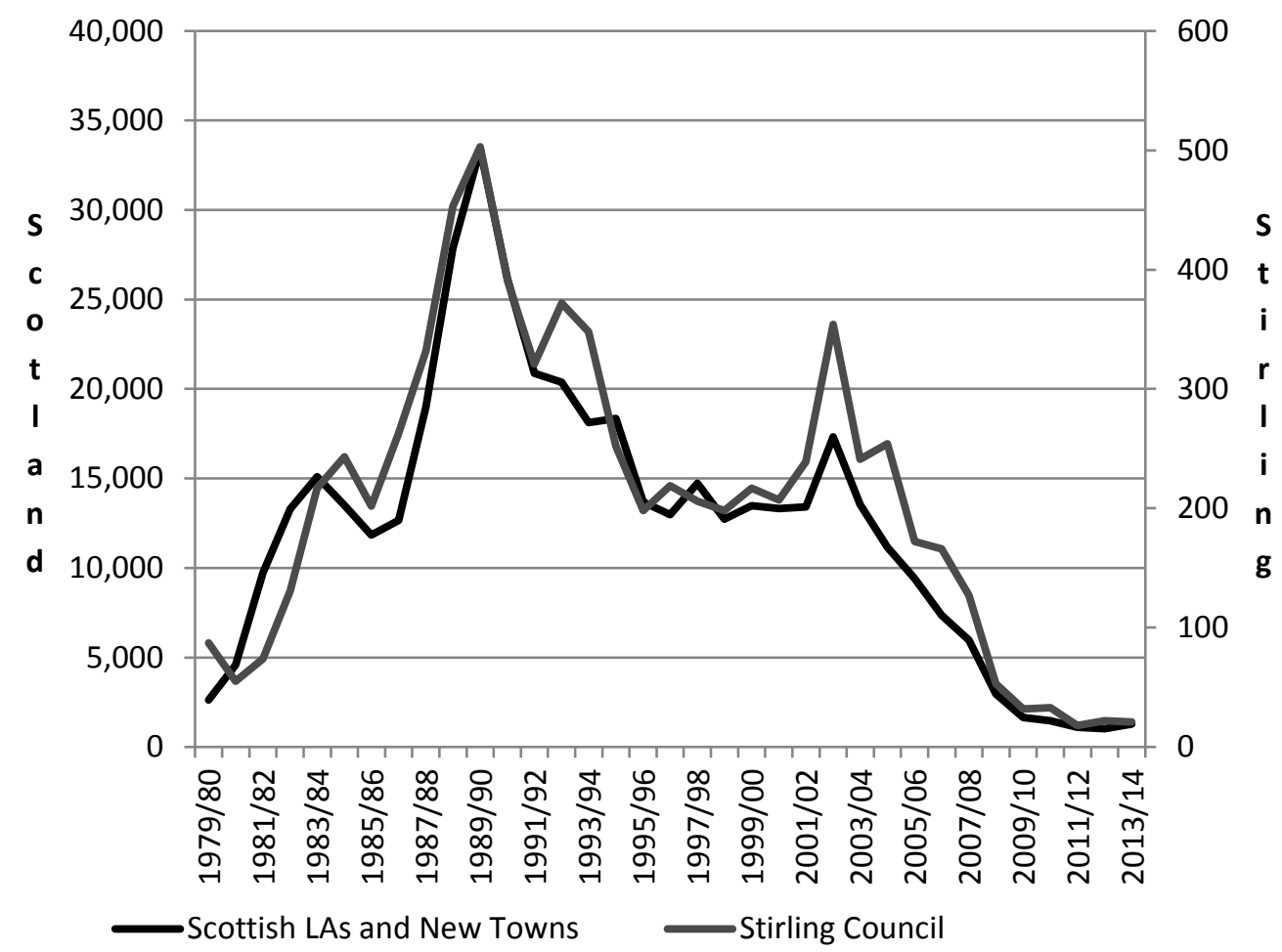

Sources: national data from the Scottish Government, http://www.gov.scot/Resource/0047/00478002.xls downloaded on June 4, 2015; Stirling Council

The increasing rates of home ownership amongst lower socio-economic status households, to which the RTB has made a significant contribution, provide vindication for the argument that the RTB '...transformed the housing market' (Jones and Murie, 2006: 119). Saunders (1990) views the right to buy as '...one of the most dramatic redistributive measures ever taken by a British government' (Saunders, 1990: 183), also acknowledging that those remaining as council tenants have become relatively poorer. Jones and Murie (2006), whilst agreeing that the uptake of RTB had a progressive redistributive effect, also argue that the differential loss of council rented properties, i.e. from the rather higher rates of sale of more desirable houses, had a regressive effect on the distribution of housing opportunities. Furthermore, for those 'winners' who did exercise the RTB, there 'appears to be a substantial differential between realised market values of former public sector homes as compared to other second-hand dwellings' (Pawson and Watkins, 1998). 
As this paper later shows, the group that saw the purchase of their home as guaranteeing them a home for life are now facing a different set of housing needs compared to the time of their purchase as they grow older. The next section explores the link between the RTB and the ageing population.

\section{The Right to Buy and the ageing population}

The concept of housing careers and aspirations is a useful framework for looking at housing markets and mobility as people move through the life cycle and to and from renting and home ownership (Kendig, 1984). Kendig (1984: 277) notes that 'the most important aspect of a housing career is the ability to attain, retain, or regain home ownership'. Clearly, home ownership is linked to aspirations, which is constrained by their income and wealth in relation to what is offered in the market, i.e. what qualities of housing are offered (including place) for what price. A housing career has been seen as a simple linear progression whilst the concept of the housing life course (van Ham, 2012) or housing pathway (Clapham, 2005) appears to offer more flexibility in looking at the ageing population and diversification of actual housing behaviours (Ong et al., 2015).

There is also increasing recognition of the wish for older people to 'age in place' and the interrelations between home, community, sociocultural contexts, faith and cultural groups (Wiles et al, 2011). This is about staying in the right place, looking at interdependence and independent living as well as how services are integrated to support ageing well (Golant 2015; McCall et al. 2018). In Wales, there has been a focus on 'last-time buyers' to support the challenges of an ageing population and increase choices at the right time in life (Phillips, 2017).

The exploration of housing pathways becomes increasingly relevant as, like many other advanced industrial societies, it is well known that the UK has an increasingly ageing population. Between 2010 and 2035 it is projected that those aged 65 and over will account for 23 per cent of the total population and those aged over 85 make up a larger proportion of that group (ONS, 2012). Analysis of the 2011 census shows that the growth between 2001 and 2011 in people aged over 50 was equivalent to 98 per cent of the rise in Scotland's overall population (Griffiths and McCall, 2015). 
Furthermore, this ageing population is likely to show enduring housing-related inequalities ${ }^{6}$. For example, the 2011 Census data also show that those in social rented accommodation report more health problems (62 per cent of home owners over 65 report good health, compared to 37 per cent of those over 65 in socially rented accommodation) (Griffiths and McCall, 2015).

In Scotland, Age, Home and Community: A Strategy for Housing for Scotland's Older People: 2012 - 2021 (refreshed in 2018) outlines a series of aims centred on helping people to live independently as long as possible, adaptations and making more effective use of current stock. However, the strategy did not address how experiences are likely to be heterogeneous. The policy interest in making the most effective use of current housing stock seems to couple with a wider perception that older owners are 'hoarding housing wealth' (Griffith, 2011), not forgetting that, as Hamnett (1999) argues, the extent of housing wealth held is likely to vary significantly and spatially across Britain (reflecting differences in house prices and house price inflation) and for different sorts of household (reflecting which rungs on the housing ladder they are able to reach) (see also Searle and Smith, 2010). The picture is further complicated with tenure changes such as the number of older renters increasing in England (to 4.7 million in 2016-17 from 2 million in 1996-97) (Ministry of Housing, Communities \& Local Government, 2018) and challenges with the integration of health and social care in regards to the engagement of the housing sector (McCall et al, 2018).

The trends within the 'homeowner societies' such as the UK and Australia have shown increasing signs of diversity in housing pathways in later life with those leaving homeownership in older age more likely to need housing assistance (Ong et al., 2015). In regards to resales of RTB, the early picture indicated that most of the vendors for resales were over 55 and typically traded homes locally (although the original legislation exempted properties with age-related adaptations). However, the majority of the resales were of older (particularly 1919 Act) houses and of perceptibly better quality housing stock (Forrest et al, 1995). This suggests that for some of those who did not sell, their houses may well be of lower quality. Owners will still face

\footnotetext{
${ }^{6}$ Different cohorts of 'older people' also exhibit marked and growing differences in income (Corlett, 2017).
} 
maintenance bills and it seems likely that they will not have enjoyed house price booms to the same extent as very many home owners.

These issues of ageing, poor housing and homeowner aspirations seem to converge to the 'Perfect Storm' scenario (Care and Repair England, 2014) and suggest that the experience of older home owners in lower value houses will differ significantly. This paper now presents some quantitative and qualitative findings regarding this particular group of homeowners and perceptions around the role of the RTB policy.

\section{Methodology}

Our research looked to further the knowledge and understandings of the housing behaviours and housing needs of lower-income older owner occupiers in one Scottish local government area. For the purposes of the analysis we identified older owner occupiers as those having a household reference person aged 55 years or over. We undertook initial secondary data analysis of housing waiting lists to identify the number and characteristics of older home owners applying for social housing. The research was granted ethical approval by the University of Stirling (Spring 2014).

In addition to exploring housing market behaviours, we explored housing needs of lower income older owner occupiers, as perceived by key stakeholders in the area. Registered social landlords $(n=8)$, voluntary bodies $(n=2)$ and one private developer were interviewed either face-to-face or on the telephone, using a semi-structured interview guide. Qualitative data analysis was conducted on QSR Nvivo and other themes included motivating factors and barriers to moving home, the need for information and advice, location, housing design and future planning. Participants included registered social landlords, voluntary organisations and private developers that were known to support housing in the local area.

The findings from these interviews, in addition to the findings from the analysis of waiting lists, were used to inform the development of a survey questionnaire. The survey included questions on a range of topics including current housing circumstances, housing history and views on future house moves. It was used to explore the views and behaviour of older owner occupiers who had already considered 
changing their housing circumstances and was therefore not designed to be representative of all older home owners in the council area.

317 older owner occupiers were identified as possible interviewees from waiting lists ${ }^{7}$ and local council records of owners who had received Care and Repair services (a regionally varied scheme of assistance for older owner occupiers aged 60 and over for repair and home improvement) in 2013-14 (cross-referenced with postcode areas of lower housing market values as recognizable in the Register of Sasines' data on house purchases in the council area in 2012) ${ }^{8}$. The Stirling council area has tended to see house prices somewhat above the national average: for example the median price of all transactions in Stirling was $£ 139,000$ in 2013-14 (compared to $£ 130,000$ in Scotland) whilst the lower quartile price was $£ 90,000$ (with Scotland as a whole at $£ 82,500)^{9}$.

After potential participants were contacted about the study and given an option to opt out, a total of 101 interviews were completed face to face via structured questionnaires between June and July 2014, meaning a response rate of $32 \%$. Tables 2 and 3 show that the majority of respondents were aged 76-85 and lived in single person households:

Table 2 Age (banded) of respondent

\begin{tabular}{lll}
\hline \hline Age Group & Frequency & Percent \\
\hline $56-65$ & 17 & $16.8 \%$ \\
$66-75$ & 31 & $30.7 \%$ \\
$76-85$ & 46 & $45.5 \%$ \\
86 or higher & 7 & $6.9 \%$ \\
Total & 101 & $100.0 \%$ \\
\hline \hline
\end{tabular}

\footnotetext{
${ }^{7}$ Included at the request of commissioners, approximately 30 households in the sample were drawn from this database.

${ }^{8}$ The respondents to the survey had tended to have few house purchases and, in many cases, had not moved for a long time. We do not, therefore, have any direct observation of the value of their houses. We sampled in postcode sectors of relatively low value, and infer from this that we have achieved interviews with households likely to receive relatively low prices should they sell their homes.

${ }^{9}$ These data are not mix-adjusted and may therefore reflect differences in the characteristics of houses transacted as well as the relative balances of supply and effective demand; data sourced from the Register of Sasines.
} 
Source: Household survey

Table 3 Respondent household type

\begin{tabular}{lll}
\hline Household type & Frequency & Percent \\
\hline Single person & 43 & $43.0 \%$ \\
Couple, no others & 36 & $36.0 \%$ \\
Single person and (grand)sons/ & 9 & $9.0 \%$ \\
(grand)daughters, including adopted & & \\
son/daughter and foster child) & & \\
Couple and (grand)sons/ & 10 & $10.0 \%$ \\
(grand)daughters, including adopted & & \\
son/daughter and foster child) & & \\
Single person and other relation & 1 & $1.0 \%$ \\
Single person and carer & 1 & $1.0 \%$ \\
Unknown & 1 & $1.0 \%$ \\
Total & 101 & $100.0 \%$ \\
\hline \hline
\end{tabular}

Source: Household survey

The relatively low response rate, coupled with the nature of the sampling frame (see above) means that it would not be appropriate to make wide generalizations from the data obtained but to use them illustratively ${ }^{10}$. Respondents lived across the Council area and were largely retirees (with slightly more aged under 75 than over). $85 \%$ were retired and a further $3 \%$ described themselves as permanently sick or disabled. Approximately $10 \%$ were working part or full time, self-employed or had some irregular earned income. Approximately $30 \%$ of the respondents were reported as having both an impairment and/or long-term illness and being disabled in a way that limited daily activities. The proportions were highest amongst owners in the 76-85 age band.

\footnotetext{
${ }^{10}$ The fact that we do not have a truly representative sample of all older home owners means that the data are likely to exclude many people who are housed adequately according to their needs, either as a result of the characteristics of the house, any aids and adaptations or through having moved.
} 


\section{Findings: The legacy of the Right to Buy}

The research that we carried out did not initially have a specific focus on the Right to Buy as we were investigating the needs of older owner occupiers in lower value housing and exploring their housing options. Yet, two thirds of the sample of owners interviewed lived in a house they had bought under the RTB, and a further $6 \%$ lived in a resold former council house ${ }^{11}$. Even acknowledging that the sample construction may have been likely to yield a high proportion of former council homes, the RTB looms very large in interviewed owners' housing careers. The majority of participants owned their home outright and were very satisfied with their current housing (Table 4 and 5):

Table 4 Respondent housing tenure

\begin{tabular}{lll}
\hline Tenure & Frequency & Percent \\
\hline Buying with mortgage/loan & 18 & $17.8 \%$ \\
Own outright & 75 & $74.3 \%$ \\
$\begin{array}{l}\text { Rents (including rents paid } \\
\text { by housing benefit and }\end{array}$ & 8 & $7.9 \%$ \\
rent free) & & \\
Total & 101 & $100.0 \%$ \\
\hline
\end{tabular}

Source: Household survey

Table 5 Satisfaction with current house

\begin{tabular}{|c|c|c|}
\hline Satisfaction & Frequency & Percent \\
\hline Very satisfied & 76 & $75.2 \%$ \\
\hline Fairly satisfied & 22 & $21.8 \%$ \\
\hline $\begin{array}{l}\text { Neither satisfied } \\
\text { dissatisfied }\end{array}$ & 2 & $2 \%$ \\
\hline Fairly unsatisfied & 1 & $1 \%$ \\
\hline Very unsatisfied & 0 & 0 \\
\hline Total & 101 & $100.0 \%$ \\
\hline
\end{tabular}

Source: Household survey

\footnotetext{
${ }^{11}$ There were no differences in the age profile of households who had bought through the RTB and other low value home owners.
} 
32 respondents said that they didn't use any aid or adaptation to get around their house and had no need of one and one person said that s/he couldn't get round the house. The majority (over two thirds) thus did need a form of assistance and the most commonly cited were handrails (52 people), a walking stick or crutches (40) and a walking frame (13). 36 respondents said that they/a household member had some form of care or support service. These findings reveal a population of owners drawn from older cohorts of the 55+ age groups where small, and single person households dominate; very high proportions (one in three at least) either find it difficult to access all of their housing or make use of some form of care and support.

Additionally, the RTB was a strong theme in the qualitative interviews with housing associations and services. The experiences of housing professionals in this sector outlined a variety of different experiences with RTB owners who had been either looking for a social rented home or had experienced a health crisis. Furthermore, the majority of the participants in the study linked the categorisation of 'lower valued properties' with older RTB properties.

My experience ... [shows that] is really about RTB and the value of those properties and the person's ability to maintain them as owner occupied stock (Housing association manager).

Those living in RTB properties were seen as being less likely to move to a new property. Almost $58 \%$ of those with a self-defined need for housing did not expect to be able to meet it (taking the responses of 'not very likely', 'not at all likely' and 'certain not' to be able to move) (Table 6). Also, nearly half (46.2\%) had previously lived in the same neighbourhood/village as their current home. Looking at people's reasoning more closely, the most common explanations were that people were "happy in their current house" or that they were "too old to move" or "they couldn't afford the price" of a new home. 
Table 6 Likelihood of moving to property of choice

\begin{tabular}{lll}
\hline How likely, if at all, do you think it is that you will be & Frequency & Percent \\
able to move to the type of property you would most & \\
like to live? & 2 & $2.2 \%$ \\
\hline Certain to be able to & 8 & $8.7 \%$ \\
Very likely to be able to & 20 & $21.7 \%$ \\
Fairly likely to be able to & 16 & $17.4 \%$ \\
Not very likely to be able to & 28 & $30.4 \%$ \\
Not at all likely to be able to & 9 & $9.8 \%$ \\
Certain not to be able to & 9 & $9.8 \%$ \\
Already live in it & 9 & - \\
Don't know/missing & 101 & $100.0 \%$ \\
Total & & \\
\hline \hline
\end{tabular}

Source: Household survey

The inability to move in the owner occupied market related to the perceived potential resale value of their house. Furthermore, there was recognition, borne out by findings from owners themselves, that people taking up the RTB saw that as fulfilling their housing aspirations:

But people see their RTB houses as a house for life. Because it's cheaper than paying rent (Housing association interview).

Well an obvious issue is people able to cash in on equity - an RTB property will not get them a nice bungalow (Housing association interview).

Therefore, the wider stakeholders viewed current RTB owner occupiers as a group that had their housing choices limited through low equity, which was constraining their ability to buy another house. However, their preference to remain in their home clearly indicates an unwillingness to buy a different property.

Approximately two thirds of owners surveyed did not want or expect to move, commonly because of attachment to their current house, neighbourhood or village. 
As is well recognised in the literature (see the review by Maclennan, 2012), houses are locationally fixed: buying or renting a house means simultaneously acquiring the characteristics of its neighbourhood, its environment, and its local public and private services. The suggestion is that not only had RTB purchasers anticipated that their home would satisfy their long term aspirations, so too would the place they were purchasing. Further corroboration for this is seen in that $75.2 \%$ of respondents indicating they were 'very' and a further $21.8 \%$ 'fairly' satisfied with their property.

Over a third of the sample of owners used, and relied on, some form of aid or assistance to get around their house. Current homes were viewed as often unsuitable for their current health needs. The findings suggested that one of the unforeseen longterm consequences of the RTB has been to leave some buyers 'trapped' in houses that are no longer suited to their needs. The survey of owners found that approximately one household in three RTB purchasers (and $28 \%$ of all owners) had at least one member who could not get around their whole house. Rates of being unable to access the whole house were about twice as high (43\%) amongst households with an HRP aged 76-85 than amongst those with a HRP aged 56-65 (21\%); they were also higher in owners of houses rather than flats. The findings are triangulated by service providers' views:

\begin{abstract}
.. A lot of people... are currently living in unsuitable ${ }^{12}$ properties. This is mainly people who have bought their council house and it is not now suitable for their needs. For example having an upstairs toilet. The properties do not seem suitable for minor adaptions... This group tend to be people who have lived in the same home for their lifetimes, ... and they consistently have a housing issue that needs addressed before they can go home [from hospital or interim care] (Care and Housing support worker).
\end{abstract}

For service provider interviewees, the main drawbacks of being in older Right to Buy properties centred around concerns of suitability for the ageing population. This related firstly to accessibility and secondly to the costs of repairs and maintenance:

\footnotetext{
12 Here and elsewhere, the words used are the interviewee's and we did not attempt independent verification of claims made.
} 
For those who bought their house over 20 years ago. They haven't benefited from house price increases. They just carry on but they will have bad windows, kitchens, as opposed to those who benefited from market improvements and had equity (Housing association manager).

The data as a whole are suggestive of a significant proportion of owner occupiers in lower value properties being in unsuitable accommodation for their current and likely future health needs. Many within this group were in properties bought through the RTB, which can have expensive maintenance needs due to the age of the stock.

\section{Diverse health and housing needs}

The above examples highlight that some owner occupiers in older RTB properties may have changing health and housing needs. There was an indication that these homes are costly to maintain, difficult to adapt and therefore can affect access to essential parts of the house.

Although the Scottish policy on housing and ageing emphasises the importance of living at home, coinciding with the preference of most older owners (Banks et al., 2012; Clark, 2012), evidence suggests that adaptations of current housing stock, especially older and less well maintained stock, cannot be the only solution. Even in the one local authority area studied, there would appear to be a significant number of owners living in simply inadequate housing, who were looking to move but seemed to have few options available. Thus, whilst the survey of owners found that one in three households anticipated moving in the few years subsequent to interview, primarily because of 'ill health' or wanting to downsize, one in eight did not believe that a suitable house that they could afford would be available. The proportion was slightly higher for RTB purchasers but not in a statistically significant way. Service provider views corroborated this:

Housing needs are not being fully met for this group... It is the issue of life events that are random mostly as being the driving force for changing lifestyles. Makes this a hard group to work with (Care and Housing support worker). 
Others, particularly RTB purchasers and for all where HRPs were aged 76-85, stated that they were 'too old to move'. For service providers, there were differences between RTB purchasers and other owner occupiers:

Those who have built their way up the housing ladder - rather than those who are still in their right to buy - are better at adapting and downsizing as they have experience of the market. The thought is less daunting to them (Care and Housing support worker).

\section{Furthermore:}

In addition to financial barriers, there may be barriers in terms of health and ...family links. Education may be a further barrier, as may the fact that many people who are in lower value properties may have purchased these through right to buy schemes and as such may have no experience of looking at property, purchasing property or indeed the practicalities of moving from an owned property (Notes from interview with volunteer).

Further to cultural and financial barriers, the findings suggest that for this group the transition into other accommodation is usually influenced strongly by a health crisis and/or lack of options. This complements other research: for example, Shelter (2012) found that older RTB purchasers, especially those in ill health, were more likely to get into financial difficulties and face arrears and repossession. When participants were asked what the main motivating factors were to move house, health emerged strongly:

Critical life events, especially connected to health and disabilities (Housing support worker).

There are more present issues in lower value of the houses and you have the more pervasive issues of confidence, health and feelings of safety and security (Housing Association CEO).

Health was also perceived as presenting a high barrier to moving: 
This is linked to a difference in culture as they have lived in the same house all their lives and an alternative would seem overwhelming - especially if their crisis has been brought on by a health issue or major life event (Housing support worker).

It was recognised that a health crisis would be likely to force a move to a house that the home owner had not chosen, taking away their control and sense of agency. For this group, a move to social rental in particular would mark an unwelcome turn of their housing career, perceived as a 'step down' the housing ladder. All owners surveyed strongly identified with that status and wished to stay homeowners. This was no less true amongst those who had applied for social housing. Home owners rejected renting as they 'wanted their own house' and renting (in either social or private sectors) was a 'waste of money'. Intermediate tenures, such as shared equity or shared ownership, were barely recognised. This mirrors other findings in the sector that outline shared ownership arrangements, for example, as being complex and confusing for prospective owners, especially resale buyers (Cowan et al., 2015). In these respects, the views of the home owners surveyed are no different to those repeated in other survey evidence on the advantages and disadvantages of different tenures (Jones and Murie, 2006, Saunders, 1990) but their experiences of being homeowners diverged greatly.

\section{Discussion}

We see evidence of a divergence between homeowners in the forms of not only income and wealth inequalities but also being able to cope with changing health needs. The findings have indicated that as some home owners have grown older, the consequences of their RTB purchase have had a vital part to play in their current motivation and ability to move home. Wider stakeholders in the housing sector working in local authority, housing associations and the voluntary sector have indicated a clear link between the RTB and older owner occupiers in lower value properties. By treating the initial RTB property as a lifetime home, there is a perception that those with low equity and low income have limited housing choices in older age. At the same time, aspirations of home owners recorded here are in line with Goodlad and Atkinson's (2004, p. 457) research that noted that those who benefited from the RTB had also 
bought the idea that the RTB was an instrument of wealth creation, independence and that 'the working poor have benefited, people have never looked back'. Treating both the ageing population and homeowners as homogenous groups has overlooked the both wealth and health inequalities.

The research reported here suggests that not all older home owners have seen unequivocal benefits from taking up the Right to Buy. The influence of economic constraints and the influence of socioeconomic determinants such as health and debt (Ong et al., 2015) remain key restraints and have had a role in differentiating older home owners as a group. This challenges the perceived idea of 'generational wars', an often cited media narrative commonly focused on access to housing (SpiesButcher, 2014). The paper adds to Hoolachan and McKee's (2018) conclusions that inter-generational inequalities are much more nuanced and can be misleading in regards to blame. This paper highlights that limitations in access and housing choice is not only experienced by younger generations, but also sub-sets of older home owners.

Furthermore, the interconnection of health and social issues in older age and the suitability of homes concurs with the increased consideration of the complexities of 'ageing in place' and the need to consider 'access to and familiarity with social networks, transport and health services, and a wide variety of amenities [that] underpin the preference for aging in place (Wiles et al. 2011). The research has shown that there are symbols and identities attached to the Right to Buy in the housing sector, which add complexities to the ability to 'ageing in place'. There is a need to focus on 'right-sizing' at the end of life in a way that empowers older people and increasing their sense of place and belonging (Means, 2007, Golant, 2015, Phillips, 2017, McCall et al, 2018,). There is no 'one-size-fits-all aging in place solution' and the current emphasise in policy about remaining in current homes should instead be about being in the right home in the right place (Golant, 2008: 393). Our findings reinforce this indicating that some owner occupiers are simply in inadequate housing, but also do not see themselves as likely to move. The Welsh solution of looking at last-time buyers' through equity release and help to buy schemes is a key policy intervention that could support housing choice in older age (Phillips, 2017). This suggests more 
policy focus is needed on home owners at the other end of the scale as they age, not only on younger first time buyers.

\section{Conclusion}

This paper challenges both the notions of homeowners and older people as being homogenous groups. We see in our examination to the legacy of the Right to Buy policy emerging insights to both wealth and health inequalities that give insight to the picture of owner occupiers on lower incomes. A caveat to this study, however, is its local context, scale and scope. Owner occupiers in lower value properties are a difficult group to access and support. Our research suggests, however, that there is an emerging group of older home owners living in houses that do not suit their current, or likely future, needs (especially in regards to health). Interviews with voluntary sector care, advocacy groups and social landlords point to the potential vulnerability of older owner occupiers in older homes, on lower income and limited equity. We thus challenge assumptions in 'generational wars': not all those who gained from the RTB are winners, they include people with more limited equity and limited housing choices.

This legacy of the Right to Buy in Scotland represents an ongoing concern, in which focus on maintenance, repairs and supporting 'right-sizing' is essential for helping older home owners on lower incomes 'age - (well) - in - place' (Golant, 2015, McCall et al, 2018, Phillips, 2017). We suggest a renewed policy focus on increasing housing choice for older people through schemes similar to those offered to first-time buyers in the UK to enable access to suitable housing as they grow older.

\section{References}

Banks, J., Blundell, R., Oldfield Z., and Smith, J. P. (2012) 'Housing Mobility and Downsizing at Older Ages in Britain and the USA', Economica, 79, 1-26.

Care and Repair England (2014) A Perfect Storm: An ageing population, low income home ownership, and decay of older housing, Care and Repair England: Nottingham

Clark, W.A.V. (2012) 'Residential mobility and the housing market', in Clapham, D., Clark, W.A.V. and Gibb, K. (eds.), The SAGE Handbook of Housing Studies, London: SAGE. 
Clapham, D. (2005) The Meaning of Housing: A Pathways Approach, Bristol: Bristol University Press.

Corlett, A. (2017) As time goes by: shifting incomes and inequality between and within generations, London: Resolution Foundation, http://www.resolutionfoundation.org/app/uploads/2017/02/IC-intra-gen.pdf on [accessed from 13.02 2017].

Cowan, D. Wallace, A. and Carr, H. (2015) Exploring experiences of shared ownership housing: reconciling owning and renting, https://www.york.ac.uk/media/chp/documents/2015/sharedOwnershipCHPL.pdf [accessed 13.02 2017].

Dorling, D. (2015) 'Policy, politics, health and housing in the UK', Policy and Politics, 43, 2, 163-180.

Forrest, R. and Leather, P. (1998) 'The ageing of the property owning democracy', Ageing \& Society, 18, 1, 35-63.

Forrest, R., and Murie, A. (1985) Restructuring the welfare state: Privatization of public housing in Britain. In W. van Vliet, E. Huttman, \& S. Fava (Eds.), Housing needs and policy approaches: Trends in thirteen countries Durham: Duke University Press, 97-109.

Forrest R. and Murie A. (1988) Selling the Welfare State: The Privatisation of Public Housing, $2^{\text {nd }}$ edition, London: Routledge.

Forrest R. and Murie A. (1990) Moving the Housing Market Avebury: Aldershot.

Forrest, R., Murie, A. and Gordon, D. (1995) The resale of former council homes, Housing Research Report for the Department of the Environment, London: HMSO.

Forrest, R., Murie, A. and Williams, P. (1990) Home ownership: Differentiation and fragmentation, London: Hyman.

Gibb, K. (2014) 'Housing policy in Scotland since devolution: divergence, crisis, integration and opportunity', Journal of Poverty and Social Justice, 23, 1, 29-42.

Golant, S. M. (2008). 'Commentary: Irrational exuberance for the aging in place of vulnerable low-income older homeowners', Journal of Aging and Social Policy, 20, 4, 379-397

Golant, S. M. (2015) Aging in the Right Place Baltimore: Health Professions Press. Goodlad R., and Atkinson, R. (2004) 'Sacred cows, rational debates and the politics of the right to buy after devolution', Housing Studies, 19, 3, 447-463. 
Griffith, M. (2011) Hoarding of Housing: The intergenerational crisis in the housing market, Intergenerational Foundation.

Griffiths, D. and McCall, V. (2015) Growing older in Scotland: health, housing and care. 2011 census data analysis, Research Briefing for the Equalities and Human Rights Commission.

Hamnett, C. (1999) Winners and losers: Home ownership in modern Britain, London: Taylor and Francis.

Hills, J., Cunliffe, J., Gambaro, L. and Obolenskaya, P. (2013) Who won and who lost as the economic crisis hit? Changing inequality in the UK, 2007-2010, Summary Research Report 2, CASE, LSE, JRF, Nuffield and Trust for London. Hoolachan , J. and McKee, K. (2018) 'Inter-generational housing inequalities: perspectives from 'Baby Boomers' versus the 'Millennials' ' Urban Studies, vol. OnlineFirst . https://doi.org/10.1177/0042098018775363

Jones, C. A. and Murie, A. (1999) 'Stability and change in council estates: the Right to Buy', Housing and Planning Review, 54, 2, 11-12.

Jones, C. and Murie, A. (2006) The Right to Buy: Analysis and evaluation of a housing policy, Oxford: Blackwell.

Kendig, H.L. (1984) 'Housing careers, life cycle and residential mobility: Implications for the housing market', Urban Studies, 21, 271-283.

Leather, P. and Moseley, R. (2002) Investment in housing: towards better policies for repairing and improving the housing stock, York: Joseph Rowntree Foundation, http://www.jrf.org.uk/sites/files/jrf/1859353835.pdf, [accessed 02.06.2015].

Maclennan, D. (2012) 'Understanding housing markets: real progress or stalled agendas?', pp 5-26 of Clapham, D.F., Clark, W.A.V. and Gibb, K. (eds) The SAGE Handbook of Housing Studies, London: SAGE.

Means, R. (2007) 'Safe as Houses? Ageing in Place and Vulnerable Older People in the UK', Social Policy and Administration, 41, 1, 65-85.

McCall, V., Eadie, J., Lovatt, M., Maclntyre, Z., Phillips, J., Porteus, J., Robertson, J., Rutherford, A., Sixsmith, J. Woolrytch, R., Ziegler, F. (2018) Housing and Ageing: Linking strategy to future delivery for Scotland, Wales and England 2030, Glasgow: Scottish Universities Insight Institute.

McKee, K. (2010) 'Promoting homeownership at the margins: the experience of lowcost homeownership purchasers in regeneration areas', People, Place and Policy Online, 4, 2, 38-49. 
McKee, K. (2011) 'Challenging the Norm? The 'Ethopolitics' of Low-cost Homeownership in Scotland', Urban Studies, 48, 16, 3399-3413.

McKee, K. Muir, J. and Moore, T. (2016) 'Housing policy in the UK: the importance of spatial nuance', Housing Studies, 32, 1, 60-72.

Merrett, S. and Gray, F. (1982) Owner occupation in Britain, London: Routledge and Kegan Paul.

Ministry of Housing, Communities \& Local Government. (2018) English Housing Survey 2016 to 2017: private rented sector, https://www.gov.uk/government/statistics/english-housing-survey-2016-to-2017private-rented-sector [accessed 14.02.2019].

Murie, A. (2016) The Right to Buy? Selling off Public and Social Housing, Bristol: Policy Press.

Office of National Statistics (2012) Population Ageing in the United Kingdom, its Constituent Countries and the European Union, London: ONS.

Ong, R., Wood, G.A. and Colic-Peisker, V. (2015) 'Housing older Australians: Loss of homeownership and pathways into housing assistance', Urban Studies, 52, 16, 2979-3000.

Pawson, H. and Watkins, C. (1998) 'The Position and Role of Former Public Sector Homes in the Owner-occupied Sector: New Evidence from the Scottish Housing Market', Urban Studies, 35, 8, 1291-1309.

Pierson, P. (1994). Dismantling the Welfare State?: Reagan, Thatcher and the Politics of Retrenchment, Cambridge Studies in Comparative Politics. Cambridge: Cambridge University Press.

Phillips, J. and the Expert Group on Housing and Ageing Population in Wales (2017) (2017) Our Housing AGEnda: meeting the housing aspirations of older people in Wales, Cardiff: Welsh Government Saunders, P. (1990) A nation of home owners, London: Unwin Hyman.

Scottish Government (2013) The future of the Right to buy in Scotland, consultation report, http://www.gov.scot/Resource/0042/00427521.pdf, [accessed 27.01.2016].

Scottish Government (2014) End in sight for Right to Buy, http://news.scotland.gov.uk/News/End-in-sight-for-Right-to-Buy-bcc.aspx, [accessed 27.01.2016] 
Scottish Government (2015) High Level Summary of Statistics data for Housing and Regeneration trends, web publication, http://www.gov.scot/Resource/0047/00471777.xls [accessed 28.04 2015].

Searle, B.A. and Smith, S.J. (2010) Housing Wealth as Insurance: Insights from the UK, chapter 15 of Smith, S.J. and Searle B.A. (eds) The Blackwell Companion to the Economics of Housing: the Housing Wealth of Nations, sourced from http://www.blackwellreference.com/public/book.html?id=g9781405192156 97814 $\underline{05192156}$ [accessed 20.05.2016].

Select Committee on Public Service and Demographic Change (2013) Ready for Ageing?, London: House of Lords, http://www.publications.parliament.uk/pa/ld201213/ldselect/ldpublic/140/140.pdf, [Accessed 27.09.2016].

Shelter (2012) Department for Communities and Local Government Consultation: Reinvigorating the Right to Buy and One for One replacement, London: Shelter. Spies-Butcher, B. (2014) Generational war: a monster of our own making, The Conversation, http://theconversation.com/generational-war-a-monster-of-our-ownmaking-35469 [Accessed 27.05.19]

Revell, K. and Leather, P. (2000) The State of UK Housing (2nd edition): A factfile on housing conditions and housing renewal policies in the UK, York: Joseph Rowntree Foundation.

Van Ham, M. (2012) 'Housing behaviour', pp 47-65 of Clapham, D.F., Clark, W.A.V. and Gibb, K. (eds) The SAGE Handbook of Housing Studies, (London: SAGE).

Walker, A. (1981) Towards a Political Economy of Old Age. Ageing \& Society, 1, 1, 73-94

Wilcox, S., Perry, J. and Williams, P. (2015) UK Housing Review, 2015, Coventry: Chartered Institute of Housing (Table 17 available from http://www.york.ac.uk/res/ukhr/ukhr15/tablesandfigures/excel/15-017a-d.xls [accessed on 28.04.2015].

Wiles, J.L., Leibing, A., Guberman, N., Reeve, J. and Allen, R.E.S. (2011) 'The Meaning of "Aging in Place” to Older People', Gerontologist, 52, 3, 357-366. Williams, N.J. and Twine, F.E (1992) 'Increasing Access or Widening Choice: The Role of Resold Public-Sector Dwellings in the Housing Market', Environment and Planning A, 24, 11, 1585-1598. 
